\title{
Promoting customer brand engagement and brand loyalty through customer brand identification and value congruity
}

Customer brand engagement and brand loyalty

\section{Creación de la conexión emocional y lealtad con la marca a través de la Identificación marca-consumidor y congruencia de valores}

\author{
Raouf Ahmad Rather \\ The Business School, University of Jammu, Jammu, India \\ Shehnaz Tehseen \\ Sunway University, Bandar Sunway, Malaysia, and \\ Shakir Hussain Parrey \\ University of Kashmir, Srinagar, India
}

\begin{abstract}
Purpose - On the basis of the social identity and congruity theories, the present research aims to propose that value congruity directly affects customer-brand identification (CBI), affective brand commitment and customer-brand engagement (CBE), which, in turn, paves the way for advancing consumer relationships with hospitality brands, as measured through brand loyalty. As such, this study serves to enhance existing insight into customer relationship management dynamics, with a particular focus on hospitality brands.
\end{abstract}

Design/methodology/approach - The present study develops a theoretical framework that is empirically investigated by using confirmatory factor analysis and structural equation modelling analyses. Data were collected by using a self-administered questionnaire of 340 customers of four- and five-star hotel brands in India.

Findings - The results suggest value congruity as an important driver of CBI, affective commitment and $\mathrm{CBE}$ within hospitality brands. The results also reveal $\mathrm{CBI}$ to act as a significant predictor of affective

(C) Raouf Ahmad Rather, Shehnaz Tehseen and Shakir Hussain Parrey. Published in Spanish Journal of Marketing - ESIC. Published by Emerald Publishing Limited. This article is published under the Creative Commons Attribution (CC BY 4.0) licence. Anyone may reproduce, distribute, translate and create derivative works of this article (for both commercial and non-commercial purposes), subject to full attribution to the original publication and authors. The full terms of this licence maybe seen at http://creativecommons.org/licences/by/4.0/legalcode

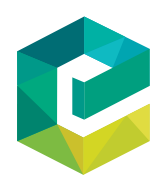

Spanish Journal of Marketing Vol. 22 No. 3 . 2018 pp. $321-339$ Emerald Publishing Limited 2444-9709 DOI 10.1108/SJME-06-2018-0030 

of loyalty to hospitality brands.

Research limitations/implications - The research is exploratory in nature and is restricted to fourand five-star hotel customers, thereby reflecting important limitations of this study. Given these issues, ample opportunities exist for further research to further explore and/or validate the reported findings.

Practical implications - The current research provides new insights for marketing practitioners planning or implementing long-term customer relationship management strategi3es that centre on customerbrand identification, customer-brand engagement and brand loyalty.

Originality/value - Despite existing insights, empirical investigation into the proposed conceptual relationships remains limited to date, particularly in the hospitality industry. By offering empirical evidence in this area, this study adds to the extant body of knowledge on CBI/CBE-centric customer relationship management.

Keywords Brand loyalty, Customer brand engagement, Affective brand commitment, Customer brand identification, Hospitality brands, Value congruity

Paper type Research paper

\section{Resumen}

Propósito - Sobre la base de los planteamientos teóricos de las Teorías de la identidad social y de la congruencia, este trabajo propone que la congruencia de valores afecta directamente a la identificación del consumidor con la marca, al compromiso afectivo y vínculo emocional con la misma, lo cual clarifica la manera con la que construir relaciones de los consumidores con las marcas hoteleras, aproximado a través de la lealtad. Es por ello que este estudio sirve para poner en valor las dinámicas existentes actualmente en la gestión de las relaciones con los clientes con un particular énfasis en el mercado hotelero.

Diseño/metodología/enfoque - Este trabajo desarrolla un marco teórico que es empíricamente contrastado a través del análisis de ecuaciones estructurales. Los datos fueron recogidos a partir de cuestionarios auto-administrados a una muestra de 340 clientes de hoteles de 4 y 5 estrellas en la India.

Resultados - Los resultados sugieren que la congruencia de valores es un importante factor explicativo de la identificación del consumidor con la marca, el compromiso afectivo y el vínculo emocional con las marcas de hoteles. También se demuestra que la identificación con la marca actúa como un significativo predictor del compromiso afectivo, el vínculo emocional y la lealtad a la marca. Adicionalmente, el compromiso afectivo y el vínculo emocional ejercen un efecto significativo en la lealtad con la marca.

Limitaciones de la investigación/implicaciones - Esta investigación tiene una naturaleza exploratoria y sus resultados se limitan al contexto de los hoteles de 4 y 5 estrellas. Sobre la base de los resultados obtenidos, se abre un amplio número de oportunidades para el desarrollo de futuras investigaciones que confirmen validez de los resultados obtenidos.

Implicaciones prácticas - Los resultados obtenidos proporcionan interesantes líneas de actuación para que los directivos de marketing planifiquen e implementen sus estrategias de desarrollo de relaciones con los clientes en torno a la identificación con la marca, el vínculo emocional y la lealtad hacia la misma.

Originalidad/valor - Las evidencias empíricas existentes hasta la fecha son bastantes limitadas hasta la fecha, en particular en la industria hotelera. En este sentido, el presente trabajo proporciona evidencias empíricas en este ámbito y enriquece la literatura existente sobre la gestión de las relaciones con los clientes bajo un enfoque de identificación y vínculo emocional con la marca.

Palabras claves - Vínculo emocional con la marca, congruencia de valores, identifícación del consumidor con la marca, lealtad de marca, marcas hoteleras

Tipo de artículo - Artículo de investigación

\section{Introduction}

The power of branding is well acknowledged in tourism as well as hospitality brands (So et al., 2017; Rather, 2017). For many years, brands have been considered very essential in promoting strong relationships with consumers for achieving the long-term success of business. In today's market, owing to great awareness of customers regarding brands, businesses have started to use the traditional media to promote brands. However, the 
present global economic crisis has questioned regarding customer-brand engagement Customer brand (CBE), and customer-brand identification (CBI) has become very crucial for brand management.

The customer-brand engagement concept has been defined as a customers' motivationally driven volitional investment of operand/operant resources into brand interactions, and has been subject to rising scholarly attention in precedent decade (Hollebeek et al., 2016b). Customer-brand engagement is gaining rising attention, as engaged customers actively participate in new service and product development, are less price sensitive, resist switching and advocate for brands/firms (Brodie et al., 2013; Hollebeek et al., 2016b). Specified the engagement's interactive nature, service brands and/or contexts have been heralded to have particular applicability for the concept (Hollebeek, 2018; Hollebeek et al., 2016b). However, despite burgeoning attention been given to the topic of customer-brand engagement by the practitioner as well as academic communities (Brodie et al., 2013; Dessart et al., 2016; Islam et al., 2017; Odoom et al., 2017; Rather, 2018; Rather and Sharma, 2017a, 2017b), essential knowledge gaps remain. For example, the Marketing Science Institute (2016) predicted customer-brand engagement as one of the top research priorities for service firms. Despite the rising interest in developing customer-brand engagement, empirical investigation is relatively sparse, and very less has been documented about customer-brand engagement in promoting consumer behaviours, such as loyalty in an isolated model (Hapsari et al., 2017; Islam et al., 2017; So et al., 2014). While scarce investigation has been performed in customer-brand engagement relating to hospitality brand context (Rather, 2018; So et al., 2014), more comprehension of this notion is important despite its recent emergence as an essential marketing variable (Dessart et al., 2015; Hapsari et al., 2017; Hollebeek and Chen, 2014; Islam et al., 2017; Odoom et al., 2017; Rather, 2018; Rather and Shakir, 2018).

Relatedly, the existing literature does not clearly highlight the difference between developed countries and developing countries with respect to customer engagement (Odoom et al., 2017). Thus, the theoretical models used in developed countries' context usually reveal inconsistency in other countries that are less developed (Sheth, 2011); thus, studies have recommended to conduct such research in other countries using different theories as well as methodologies (Burgess and Steenkamp, 2013). Thus, the existing studies have highlighted the need to investigate customer-brand engagement across various other contexts and countries (Brodie et al., 2011; Hollebeek et al., 2016b; Odoom et al., 2017; Rather, 2018). However, more research related to customer-brand engagement has been carried out in the context of developed and/or western countries such as Australia, New Zealand and the USA (Islam and Rahman, 2016; Rather and Sharma, 2017a; Vivek et al., 2014); thus, not many studies exist on this topic in developing countries including India.

The concept of customer-brand identification or consumer brand identification creates a comprehensive understanding regarding the development of customer-brand relationship (Bhattacharya and Sen, 2003; He et al., 2012; So et al., 2017; Rather, 2017; Tuskej and Podnar, 2018). Firms have been seeking ways to build enduring and long-term relationships with their consumers and are motivated by possible positive business outcomes that can occur owing to the efforts of relationship-building (Elbedweihy et al., 2016; Rather, 2017; Tuskej and Podnar, 2018). The brand relationship literature suggests that customers do not buy brands merely because they work well. Customers also buy brands because of the meanings the brands add to their lives (Bhattacharya and Sen, 2003) and to express their self-concept (So et al., 2017; Tuskej et al., 2013). In the broader consumer context, empirical studies indicate that identification towards a brand or a company increases product use and repurchase frequency (Kuenzel and Halliday, 2008). Researchers also acknowledge that 
SJME

22,3

324

consumer identification has a significant influence on individual consumer behaviour involving: consumer buying-related decisions (Ahearne et al., 2005), brand trust and loyalty (Rather, 2017), consumer satisfaction (Martinez and Rodriguez Del Bosque Rodriguez, 2013) and resilience to negative information (Elbedweihy et al., 2016).

Although past studies offer key insights regarding the process of consumer identification and associated constructs, future studies should still fill vital gaps in such investigation. First, despite the significance of customer-brand identification as a vital predecessor of consumer behaviour (Elbedweihy et al., 2016; Lam et al., 2013), research studies acknowledge little regarding the drivers of consumer brand identification (Elbedweihy et al., 2016; So et al., 2013; Stokburger-Sauer et al., 2012; Tuskej et al., 2013; Tuskej and Podnar, 2018). However building strong relationships with consumers likely enhances their favorable attitudes and behaviors toward the brand, consumers' motivations for entering into enduring relationships with brands remain unclear (Elbedweihy et al., 2016; Rather, 2017; So et al., 2017). Second, scholars highlighted the importance to further investigate the role of consumer's identification and affective brand commitment $(\mathrm{ABC})$ on brand loyalty (Rather, 2017; Tuskej et al., 2013). Third, understudied relationships between value congruence and consumer identification (Elbedweihy et al., 2016) and value congruity (VC) and customer-brand engagement (Islam et al., 2017) has emerged as a main issue in promoting hotel brand.

Previous studies have emphasised more on the service dominant logic and relationship marketing (Brodie et al., 2011; Hollebeek et al., 2016a), or social exchange theory (Harrigan et al., 2017), as underpinning theoretical bases to exploring the phenomena of customerbrand engagement. However, there is still also a need to analyse customer-brand engagement process from various theoretical viewpoints (Harrigan et al., 2017; Islam and Rahman, 2016). In the view of above-mentioned gaps, based on social identity and congruity theories, the present research develops a model that investigates the interrelationship among VC, customer-brand identification, affective brand commitment, customer-brand engagement and customer loyalty and will fill these gaps in branding, consumer behaviour and hospitality literature.

\section{Conceptual framework}

The conceptual framework, as represented in Figure 1 elucidates the antecedents and the consequences of customer-brand identification. It is based on social identity's theories (Tajfel and Turner, 1979), along with notions from the marketing field on customer-brand

\section{Figure 1}

The conceptual model

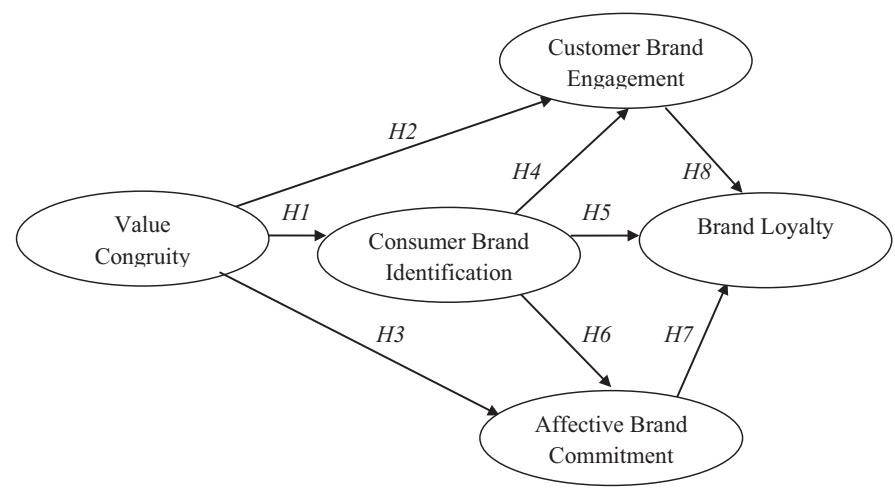


identification (Bhattacharya and Sen, 2003; Rather, 2017) and customer-brand engagement (Harrigan et al., 2017; Islam et al., 2017; Rather, 2018). The present study model proposes that $\mathrm{VC}$ influences customer-brand identification, which, in turn, influences customer-brand engagement, affective brand commitment and loyalty.

Customer brand engagement and brand loyalty

\subsection{Social identity theory}

Social identity theory (SIT) provides the basic theoretical foundation for identification in marketing as well as in organisation studies (Elbedweihy al., 2016; Lam et al., 2012). SIT states that persons classify themselves in various social categories to assist their definition of own-self (Tajfel and Turner, 1979). On the basis of SIT and organisational identification, Bhattacharya and Sen (2003) extended the identification's concept in consumer-company relationship. Despite the theory enlightening relationship marketing success for several years (Ahearne et al., 2005; Bhattacharya and Sen, 2003; Elbedweihy et al., 2016) and likely impacting on process through which consumer experiences unfold (Fujita et al., 2018), SIT's role in marketing and hospitality has been mostly underexplored (Lam et al., 2013; Martinez and Rodriguez Del Bosque Rodriguez, 2013; Rather, 2017). Furthermore, a need exists to better recognise the strategies that are expected to facilitate customer-brand engagement, a subject of research that is still in its initial phase (Fujita et al., 2018; Hollebeek, 2018). Moreover, branding theory proposes that consumers likely to identify with the brands (hotels) in several means. In addition, customers could have multiple identities such as members of a hotel brand community. Therefore, the customer-brand identification concept is based on SIT, which defines brand identification as a perceptual construct (So et al., 2013), signifying identity matching as well as identity fit.

\subsection{Congruity theory}

A number of theories have attempted to examine the consumer--brand engagement and their positive behaviours and attitudes, including relationship marketing theory (Rather, 2018; Vivek et al., 2014) and service-dominant logic (SDL; Brodie et al., 2013; Hollebeek, 2011a; Hollebeek et al., 2016a). Both the relationship marketing and service-dominant logic consider consumers to be the critical factor for brand interactions (Vargo and Lusch, 2017), therefore revealing a theoretical alignment with interactive nature of consumer-brand engagements (Brodie et al., 2011).

Congruity theory explains a person is more likely to have positive attitudes towards the object when an individual perceives an object and/or a phenomenon is consistent with what he/she holds (Lee and Jeong, 2014). It happens because of the minimum dissonance between individuals own opinions and the object (Lee and Jeong, 2014). On the basis of the congruity theory, more consistency between the two beliefs will result into the higher preference for that object such as brand or event by the individual because it acts as a symbolic attribute that serve to strengthen and confirm the existing perceptions of individuals (Islam et al, 2017; Lee and Jeong, 2014). According to the perspective of congruity theory, the customers demonstrate positive behaviours for focal brands when they had observed some positive experiences with them.

\section{3 Hypotheses development}

VC refers to the match relating to the consumers' own personal values and their perceptions of brands and/or the hotels' values (Lee and Jeong, 2014; Zhang and Bloemer, 2011). VC is dependent on similarity attraction theory (SAT; Byrne et al., 1967). SAT-informed lens explains that persons are likely to maintain relationships with other people who are similar to them. Once the VC happens, consumers expected to have more positive attitudes towards the hotel brand rather than when congruity does not take place. The self-congruity theory 
SJME

22,3

defines VC as a mental comparison, which customers make with respect to the dissimilarity and/or similarity of firm's values as well as their own set of values (Johar and Sirgy, 1991). It is under the control of managers owing to marketing and positioning activities, and can facilitate consumers to satisfy their self-definitional needs for verification and/or continuity (Tuskej et al., 2013).

Researchers have proposed VC as a key notion to maintain and develop long-standing customer relationships towards the brand/provider (Islam et al., 2017; Lee and Jeong, 2014). Values can effect significantly on customer activities or actions, and perform as key linking factors between consumers and brands/hotels (Tuskej et al., 2013). Customers likely to interact with hotel brands which facilitate them to realise their self-beliefs and self-values as more engaging as such a match legitimises and empowers their sense of self (Islam et al., 2017; Tuskej et al., 2013). As discussed in SAT (Byrne et al., 1967), the role of VC (Zhang and Bloemer, 2011) envisages that consumers are expected more to have increased hotel brand commitment and attitudes towards the brand (hotel) when they recognise VC between themselves and brand/hotel. Therefore, based on above ideas:

H1. Value congruity has a positive influence to customer-brand identification

H2. Value congruity has a positive influence to customer-brand engagement.

H3. Value congruity has a positive influence to affective brand commitment.

Tourism and hospitality contexts and/or brands have widely used branding strategies to set their services and products different from rivals (Rather, 2017; So et al., 2013), highlighting the specific importance of customer-brand identification in exploring customer-brand relationships. In tourism and hospitality, customer-brand identification is defined as "an important but underutilised construct" (Martinez and Rodriguez Del Bosque Rodriguez, 2013, p. 91). Customer-brand identification indicates a strong psychological attachment, which is indicative of future behaviour and long-term relationship (So et al., 2013). As theoretical models have proposed customer-brand identification's positive effect on customer-brand engagement (Van Doorn et al., 2010), empirical verification of this relationship remains in sufficient to-date (Romero, 2017; Tuskej and Podnar, 2018). Therefore, consumer identification can be a key antecedent of customer-brand engagement (Romero, 2017; Tuskej and Podnar, 2018; Van Doorn et al., 2010). Consumers who identify with a brand increase the engagement with the brand (Romero, 2017).

Research about customer-brand identification and hotel brand loyalty has been inconsistent thus far (Elbedweihy et al., 2016; So et al., 2013). Service brands can act a facilitator of social identity expression and creation, and consumers can identify with a service brand that they perceive to match their self-concept (Elbedweihy et al., 2016; Rather, 2017). It is owing to this that customers fulfil their self-definitional or verification needs, which, in turn, increases their attitudes or behaviours towards the service brand (Elbedweihy et al., 2016; Tuskej and Podnar, 2018). Social identity can influence individual's perceptions, cognitions and evaluations, and consumers' strong identification with a brand or offering may lead to enhanced consumer outcomes, such as higher brand loyalty (Rather, 2017; So et al., 2013). Similarly, Su et al. (2016) establish that higher shared values between service brands and their customers promote commitment with the ongoing relationship:

H4. Customer-brand identification has a positive influence to customer-brand engagement. 
H5. Customer-brand identification has a positive influence to brand loyalty.

H6. Customer-brand identification has a positive influence to affective brand commitment.

Affective commitment is an emotional factor, which develops through personal involvement or reciprocity that a consumer has towards the firm, which results in a greater level of loyalty and commitment (Fullerton, 2003; Rather, 2017). In high-tech industries, Ruyter et al. (2001) establish that more the customers' affective commitment greater is the loyalty towards suppliers. In its experimental study, Fullerton (2003) examined that greater the consumers' affective commitment, more they were willing to pay and the lower are their switching intentions. Wu et al. (2011) found that more is the affective commitment higher is the customer's loyalty in mobile communication operators. Recently, Fatma et al. (2016) identified that affective commitment is considered an essential determinant of brand loyalty; higher the affective commitment, the better customers tend to translate into higher loyalty towards retail service banks. In light of the above:

H7. Affective brand commitment has a positive influence to brand loyalty.

There exists a call to develop and test models, which explore the association among customerbrand engagement and other pertinent concepts within nomological networks (Islam et al., 2017; Rather and Shakir, 2018; Marketing Science Institute, 2016). In particular, the influence of customer-brand engagement on loyalty suggests a key confirmation of engagement's accurate marketing influence (Islam et al., 2017). Brand loyalty represents a customer's positive attitude towards a brand or offering, in addition to repeat buying behaviour (Liu et al., 2012; Rather, 2017, 2018). Especially as theoretical models have recommended customer-brand engagement's positive influence on brand loyalty (Hollebeek, 2018; Van Doorn et al., 2010; Viveket al., 2012), empirical confirmation of this relationship remains limited thus far (Hapsari et al., 2017; Harrigan et al., 2017; Islam et al., 2017; Sharma and Rather, 2016). Customers who engage with a brand and/or service-provider are expected to build positive attitudes most instantly than customers who are not engaged with the brand or provider (Harrigan et al., 2017; So et al., 2014). Such attitudes are most expected to be favourable that may guide to increased loyalty and/or patronage intent (Harrigan et al., 2017; Hollebeek, 2011b). On the basis of the above, the authors propose the following:

H8. Customer-brand engagement has a positive influence to brand loyalty.

H9. Customer-brand identification mediates the relationship between (a) VC and customer-brand engagement, (b) VC and affective brand commitment and (c) VC and brand loyalty.

\section{Research methodology}

\subsection{Sampling and data collection}

Data collection was conducted by a survey method at different locations within 15 four- and five-star hotels in six cities and/or locations of India, namely, Amritsar, Jammu, Katra, Gulmarg, Srinagar and Pahalgam. These locations/cities are main tourist destinations of India. In addition, all the 15 four- and five-star hotels are located in these particular locations. Therefore, Radisson Blu, Vivanta by Taj, Khyber Resorts, Grand Lalith, Best Western, Holiday Inn, etc. were approached for data collection. The population for this research was confined to those respondents who had stayed at these hotels at least once. Hospitality context was selected for several of reasons. Firstly, the hospitality literature widely
Customer brand engagement and brand loyalty 
SJME

22,3

\section{8}

Demographics

Gender

Male

Female

Age (years)

20-30

31-40

41-50

Above 51

Qualification

Matriculation

Graduation

Post-graduation

Others

Nationality

Indian

Foreigners

Occupation

Business

Service

Professional

Others

Reasons for travelling

Leisure

Adventure

Religious

Business

Table I.

Demographic profile of respondents
Hotel brand

Four star Five star 
identification, customer-brand engagement, affective brand commitment and brand loyalty. VC modified from Islam et al. (2017), Lee and Jeong (2014) and Vivek et al. (2014) were measured by using four items that have previously shown decent reliability in a service context. Customer-brand identification was adopted and modified from Rather (2017), Romero (2017) and Tuskej et al. (2013), and were measured by using four items and has shown satisfactory reliability previously in hospitality contexts. Affective brand commitment was adopted from the Tuskej et al. (2013) and Vivek et al. (2014) were measured from four statements. Customer-brand engagement was measured with four items modified

Customer brand engagement and brand loyalty from topical literature (Hollebeek et al., 2014). Brand loyalty was adopted from Rather's (2017), was measured using six items.

\section{Results}

\subsection{Measurement model}

A preliminary data analysis was performed initially, in which data accuracy, normality, missing values, outliers and multicollinearity of all variables were checked. After that, to assess the measurement model performance, the author performed a confirmatory factor analysis (CFA) by applying AMOS with maximum likelihood estimation. Multicollinearity tests suggest that variance inflation factor (VIF) values ranged from 1.52 to 2.38, well below the conservative threshold of 5.3 (Hair et al., 2010), signifying that the results from regression models are not influenced by any multicollinearity effect. Further, Hair et al. (2010, p. 633) defines multicollinearity as "a problematic degree of correlation among the predictor variables, which complicates the ability to explain the individual effects of the factors included in the analysis, and which may affect the estimation of the focal coefficients and their statistical significance tests". To test for multicollinearity in the data, the squared multiple correlations (SMCs) were evaluated. Particularly, multicollinearity is detected if the SMCs are close/equal to 1.0. The reported values indicated that all the values are below 1.0 (i.e. highest reported SMC was for CBE4 is 0.89), thus indicating that multicollinearity was not a significant issue in the data. The SMCs values are reported in Table II. Therefore, drawing on Anderson and Gerbing (1988), research data were analysed in two stages. Firstly, CFA was carried out to check goodness of fit, reliability and validity of measurement model. Model fitness indices attained from CFA: $\chi 2=577.474, \mathrm{df}=197, \chi 2 / \mathrm{df}$ $=2.931, \mathrm{NFI}=0.94 ; \mathrm{TLI}=0.95 ; \mathrm{CFI}=0.96 ; \mathrm{RMSEA}=0.075 ; \mathrm{GFI}=0.87 ; \mathrm{SRMR}=0.48$, representing a satisfactory measurement model fit (Hair et al., 2010). The results are reported in Table II.

\subsection{Reliability testing}

All the values of reliability were higher than the threshold level of 0.70 (Fornell and Larcker, 1981; Hair et al., 2010), confirming adequate internal consistency of scale items. Cronbach's alpha as well as composite reliability values are reported in Table III.

\subsection{Convergent validity testing}

CFA evaluated both reliability and validity of the scales. On the basis of Fornell and Larcker (1981), convergent validity was confirmed. Standard factor loadings values for all the items have been greater than $0.70(\phi<0.001)$. Furthermore, all the average variance extracted (AVE) values were more than threshold value of 0.50 , signifying convergent validity of constructs (see Table III). 


SL $\quad$ M SD SMC

Value congruity (VC)

I have a clear understanding of the core values of this brand (VC1)

I really support the intent of the core values of this brand (VC2)

I have a great deal of agreement about what this brand's core values represent (VC3)

This brand is relevant to my values and needs (VC4)

$\begin{array}{llll}0.98 & 5.42 & 1.04 & 0.88 \\ 0.97 & 5.46 & 1.01 & 0.87 \\ & & & \\ 0.73 & 5.87 & 0.41 & 0.53 \\ 0.90 & 5.48 & 0.94 & 0.80\end{array}$

Consumer-brandidentification (CBI)

I identify with this brand (CBI1)

When I talk about this brand, I usually say "we" rather than "they" (CB2)

I feel that my personality and the personality of this brand are very

similar (CB3)

I have a lot in common with other people using this brand (CB4)

Customer brand engagement (CBE)

I feel good when I use this brand (CBE1)

Using this brand makes me happy (CBE2)

Using this brand gets me to think about the brand (CBE3)

Using this brand stimulates my interest to learn more about brand (CBE4)

Affective commitment (ABC)

I get excited when I think of buying this brand $(\mathrm{ABC} 1)$

I feel rewarded when I buy this brand (ABC2)

I feel personally satisfied when I buy this brand ( $\mathrm{ABC} 3)$

I feel emotionally attached to this brand ( $\mathrm{ABC} 4)$

$\begin{array}{llll}0.81 & 3.09 & 1.46 & 0.64\end{array}$

$\begin{array}{llll}0.86 & 3.98 & 1.42 & 0.73\end{array}$

$\begin{array}{llll}0.90 & 4.18 & 1.32 & 0.81\end{array}$

$\begin{array}{llll}0.85 & 4.82 & 1.11 & 0.71\end{array}$

Brand loyalty (BL)

I would recommend this brand to someone who seeks my advice (BL1)

I would encourage friends to do business with this brand (BL2)

Table II.

I would say positive things about this brand to other people (BL3)

Measurement items, mean, standard deviation and squared multiple correlations
I would do more business with this brand in the next few years (BL4)

I am a loyal customer of this brand (BL5)

I am willing to maintain my relationship with this brand (BL6) correlation

$\begin{array}{llll}0.92 & 5.09 & 1.19 & 0.84 \\ 0.94 & 4.95 & 1.22 & 0.88 \\ 0.82 & 4.89 & 1.20 & 0.67 \\ 0.95 & 4.99 & 1.13 & 0.89\end{array}$

$\begin{array}{llll}0.91 & 4.66 & 1.25 & 0.83\end{array}$

$\begin{array}{llll}0.69 & 4.71 & 1.10 & 0.47\end{array}$

$\begin{array}{llll}0.92 & 4.55 & 1.24 & 0.84\end{array}$

$\begin{array}{llll}0.95 & 4.56 & 1.23 & 0.87\end{array}$

$\begin{array}{llll}0.88 & 5.36 & 1.01 & 0.77\end{array}$

$\begin{array}{llll}0.92 & 5.24 & 1.10 & 0.85\end{array}$

$\begin{array}{llll}0.93 & 5.15 & 1.14 & 0.87\end{array}$

$\begin{array}{llll}0.78 & 4.61 & 1.22 & 0.61\end{array}$

$\begin{array}{llll}0.85 & 4.55 & 1.30 & 0.72\end{array}$

$\begin{array}{llll}0.87 & 4.64 & 1.33 & 0.76\end{array}$

Notes: $\mathrm{SL}=$ standard loadings, $\mathrm{M}=$ mean, $\mathrm{SD}=$ standard deviation and $\mathrm{SMC}=$ squared multiple

Table III.

Discriminant validity, reliability values from $\mathrm{CFA}$

\begin{tabular}{lcccccccr}
\hline Construct & $\alpha$ & CR & AVE & BL & CBI & ABC & CBE & VC \\
\hline BL & 0.95 & 0.951 & 0.765 & 0.855 & & & & \\
CBI & 0.91 & 0.914 & 0.728 & 0.797 & 0.853 & & & \\
ABC & 0.92 & 0.928 & 0.765 & 0.823 & 0.829 & 0.875 & & \\
CBE & 0.95 & 0.950 & 0.827 & 0.846 & 0.798 & 0.859 & 0.885 & \\
VC & 0.92 & 0.944 & 0.810 & 0.808 & 0.643 & 0.713 & 0.720 & 0.890
\end{tabular}

Notes: $\alpha=$ Cronbach's alpha, $\mathrm{AVE}=$ average variance extracted, $\mathrm{CR}=$ construct reliability, $\mathrm{CBI}=$ consumer brand identification, $\mathrm{VC}=$ value congruity, $\mathrm{CBE}=$ customer-brand engagement, $\mathrm{ABC}=$ affective brand commitment and $\mathrm{BL}=$ brand loyalty. The bold diagonal factors are the square root of the variance shared between the research factors and its measures. Off diagonal factors are the correlations among the study factors 
As shown in Table III, these conditions were met, suggesting reliability. Further, the square root of average variance extracted estimates for each variable was all more than the correlations of all other variables, offering evidence for discriminant validity (Fornell and Larcker, 1981; see Table III).

Customer brand engagement and brand loyalty

\subsection{Structural equation model}

Secondly, structural model was also evaluated applying structural equation model (SEM). Overall, the structural model fit indices obtained, $\chi 2=607.208, \mathrm{df}=197, \chi 2 / \mathrm{df}=3.82$, TLI $=$ $0.94, \mathrm{CFI}=0.96, \mathrm{NFI}=0.94, \mathrm{GFI}=0.87, \mathrm{RMSEA}=0.078$ and $\mathrm{SRMR}=0.062$, indicate satisfactory model fit. The proposed model explains 78 per cent of variance in loyalty construct.

\subsection{Hypothesis testing}

The present research established significant and high impact of $\mathrm{VC}$ on customer-brand identification $(\beta=0.67, t=13.67, p<0.001)$, followed by customer-brand engagement ( $\beta=$ $0.35, t=7.47, p<0.001)$ and affective brand commitment $(\beta=0.29, t=6.28, p<0.001)$, that supports $H 1, H 2$ and $H 3$. The $H 4, H 5$ and $H 6$ were conducted to investigate the impact of customer-brand identification on customer-brand engagement $(\beta=0.57, t=10.89, p<0.001)$, customer-brand identification on brand loyalty $(\beta=0.27, t=3.92, p<0.001)$ and customerbrand identification on affective brand commitment $(\beta=0.65, t=12.49, p<0.001)$ and thus accepts all these hypotheses also. The $H 7$ was performed to explore the impact of affective brand commitment on brand loyalty $(\beta=0.21, t=2.67, p<0.01)$ and thus supports $H 7$. The $H 8$ was conducted to study the influence of customer-brand engagement on brand loyalty ( $\beta$ $=0.45, t=6.47, p<0.001$ ) and supports H8. The power of customer-brand engagement in determining brand loyalty has been established. Further, as customer engagement has a positive regression weights, demonstrating higher customer engagement can guide to higher levels of loyalty. The hypotheses testing result are displayed in Table IV.

\subsection{Mediation effects}

To study the mediating effect of customer-brand identification, the study evaluated the direct, indirect and total effects of customer's perceptions on brand loyalty. It is important to note that testing the mediating effect in a SEM framework has previously been carried out in the hospitality and tourism literature (Rather, 2018; Su et al., 2016). To test this mediation, this study follows the suggestions of Zhao et al. (2010), which performed a full analysis of the covariance structural model using bootstrap method. The current analysis tested the

\begin{tabular}{llrrrr}
\hline Hypotheses & Structural relationships & $\beta$ & $R^{2}$ & $T$ value & Result \\
\hline H1 & Value congruity $\rightarrow$ consumer-brand identification & $0.67^{* * *}$ & 0.45 & 13.67 & Sig \\
H2 & Value congruity $\rightarrow$ customer-brand engagement & $0.35^{* * *}$ & 0.71 & 7.47 & Sig \\
H3 & Value congruity $\rightarrow$ affective brand commitment & $0.29^{* * *}$ & 0.75 & 6.28 & Sig \\
H4 & Consumer-brand identification $\rightarrow$ customer-brand engagement & $0.57^{* * *}$ & 0.71 & 10.89 & Sig \\
H5 & Consumer-brand identification $\rightarrow$ brand loyalty & $0.27^{* * *}$ & 0.78 & 3.92 & Sig \\
H6 & Consumer-brand identification $\rightarrow$ affective brand commitment & $0.65^{* * *}$ & 0.75 & 12.49 & Sig \\
H7 & Affective brand commitment $\rightarrow$ brand loyalty & $0.21^{*}$ & 0.78 & 2.69 & Sig \\
H8 & Customer-brand engagement $\rightarrow$ brand loyalty & $0.45^{* * *}$ & 0.78 & 6.47 & Sig
\end{tabular}

Notes: $*=0.01 ; * *=0.05 * * * 0.001$ 
SJME

22,3

\section{2}

effects of an independent variable (VC) on dependent variables (customer-brand engagement, affective commitment and customer loyalty) through mediators (customerbrand identification). The findings show that the perception of VC towards hospitality service provider has a significant indirect impact on (customer-brand engagement, $\beta=$ $0.37, p<0.001$, affective commitment, $\beta=0.44, p<0.001$ and customer loyalty, $\beta=0.66, p$ $<0.001)$ through customer-brand identification. Thus, hospitality VC practices/activities can produce customer-brand engagement, affective commitment and loyalty directly and indirectly, through customer-brand identification, supports H9a, H9b, H9c (Table V).

\section{General discussion and implications}

\subsection{Theoretical implications}

The current study contributes to the existing literature by improving our understanding regarding (i) the effects of $\mathrm{VC}$ as main driver for customer-brand identification in the context of hospitality brands (ii) the influence of $\mathrm{VC}$ on customer-brand engagement (iii) the effect of VC on affective brand commitment (iii) the contribution of customer-brand identification in enhancing the customer-brand engagement (iv) the importance of customer-brand identification in influencing the affective brand commitment (v) the impact of customer-brand identification on brand loyalty (vi) the contribution of affective brand commitment in enhancing the brand loyalty (vii) the importance of customer-brand engagement in developing brand loyalty and (vi) the mediating influence of customer-brand identification on customerbrand engagement, affective brand commitment as well as brand loyalty.

From perspective of theoretical contributions, the current study also adds to the growing research regarding the relationship between consumer and brand/hotel (Elbedweihy et al., 2016; Islam et al., 2017; Rather, 2017; So et al., 2017; Tuskej et al., 2013) by empirically addressing the relationships among VC, customer-brand identification, customer-brand engagement, affective brand commitment and brand loyalty. This research contributes extra support to previous literature by identifying consumers who perceive congruity influences towards hotel brands, are expected to have more favourable outcomes.

The present study also contributes to customer-brand engagement literature by using customer's values and identification to attract customers to be involved with the brand and/ or firm. The perspective moves beyond company-based antecedents (e.g. brand reputations, brand characteristics, employees; Kumar and Pansari, 2016) and traditional customer-based drivers (e.g. customer satisfaction, brand attachment and trust) to understand customerbrand engagement (van Doorn et al., 2010). Given the potential benefits resulting from customer-brand engagement, earlier research has focused on recognising proper marketing initiatives (Pansari and Kumar, 2017) to attract customer's involvement with business. Marketing activities such as advertising (particularly celebrity endorsement) and sales

\begin{tabular}{llccc}
\hline & Relationship & Direct effects & Total effects & Indirect effects \\
\hline H9a & $\begin{array}{l}\text { Value congruity } \rightarrow \text { consumer-brand } \\
\text { identification } \rightarrow \text { customer-brand engagement }\end{array}$ & $0.353^{* * * *}$ & $0.731^{* * * *}$ & 0.378 \\
H9b $\quad \begin{array}{l}\text { Value congruity } \rightarrow \text { consumer-brand } \\
\text { identification } \rightarrow \text { affective brand commitment } \\
\text { Halue congruity } \rightarrow \text { consumer-brand } \\
\text { identification } \rightarrow \text { brand loyalty }\end{array}$ & $0.288^{* * *}$ & $0.719 * * *$ & 0.431 \\
\hline
\end{tabular}

Table V.

Notes: $*=0.01 ; * *=0.05 ; * * * 0.001$ 
promotion could be costly to the company. The $\mathrm{VC}$ and customers identification perspective needs minimum effort from the brand firm to engage customers as both perspectives persuade volitional engagement in that customers wish to be engaged for their own benefits (Islam et al., 2017; Rather, 2017; Tuskej and Podnar, 2018).

The present study empirically reveals significance of customer's identification as a basic psychological process, which assists in the development of committed and deep relationships with offerings/brands. Therefore, SIT serves as a lens to examine the consumer brand identification. Additionally, SIT has been used widely in tourism and hospitality research, and serves as an underpinning theory to study the customer behaviour and customer-brand identification. As a result, the customer-brand identification reinforces affective commitment, engagement and brand loyalty of the individuals.

Consistent with the research on VC and consumer identification by Tuskej et al. (2013), this study also reveals that VC positively impacts the customer-brand identification, then through identification, VC impacts customer-brand engagement, affective commitment and brand loyalty. The study finds that VC is an important predictor of customer-brand identification, brand engagement and affective commitment across hotel brands. This result shows the greater importance of $\mathrm{VC}$ in developing deep and enduring relationships with consumers.

Theoretically, the study model also offers a step towards the understanding of stated congruity influence on customer-brand engagement, which particularly remains missing in literature thus far. As past research has examined customer-brand engagement mostly from relationship marketing or service-dominant logic outlooks (Brodie et al., 2011; Vargo and Lusch, 2017), the study adopted congruity theory informed lens of customer-brand engagement provides additional theoretical knowledge of this conceptual association. In general, the present research adds to the literature of customer-brand engagement by validating the role of customer-perceived congruity effects in hospitality (hotel) contexts, which render customers likely to build favourable perceptions and/or strengthening positive behaviours towards their focal hospitality brand. Secondly, as the importance of congruity effects has been acknowledged in earlier research, incorporating retail (Zhang and Bloemer, 2011), health care (Erkutlu and Chafra, 2016) and online brand communities (Islam et al., 2017; Lee and Jeong, 2014), the role of congruity theory within hospitality contexts remained unexplored thus far. Therefore, the current research acts as a stepping-stone in offering increased understanding of the role of congruity effects on customer-brand engagement within hospitality brands/contexts.

Finally, the present research also contributes to literature of customer-brand engagement and brand identification owing to the conduction of its empirical work in an emerging or developing context, thus providing an early knowledge of hospitality brand-based identification and engagement in an emerging or developing context (Hollebeek, 2017; Rather, 2017).

\subsection{Managerial implications}

The present study also provides vital information for the process of customer-brand engagement and has provided some implications for making managerial choices in developing strong and long-term relationships with customers. As stated by Brodie et al. (2011, 2013), customer-brand engagement should focus on brand management directives and/or corporate strategies in present dynamic and interactive environments.

Customer-brand engagement is conceptualised as a prerequisite for financial profitability owing to increasing customer-brand relationship (Kumar and Pansari, 2016) and customer loyalty (Rather, 2018; Vivek et al., 2012). Hospitality brand marketers make every endeavour to engage customers for positive outcomes. Such endeavours (e.g. brand reputation techniques, aggressive promotions, premium customer service, creating online 
SJME

22,3

brand community, etc.) are usually costly to the brand firms and businesses. The finding that VC and customer-brand identification are significantly related to customer-brand engagement provides hospitality brand marketers a cost-effective approach to enhancing revenue by focusing on customer values and identification. The factors underlying these motives are self-identity, social status and concept. The value system effects customer's decision-making throughout the purchasing process. Therefore, it is necessary for marketers to uncover these motives and design appropriate marketing practices/strategies relating these motives to reduce cost. Hospitality brand marketers should also go beyond business profitability focus to look into the positive consequences for individual customers.

The results suggests that VC positively influences customer-brand identification, customer-brand engagement and affective brand commitment, and therefore, hotel managers need to recognise the values that are believed to be important to their target consumers. The present study, thus, suggests that one way of getting customers to identify, to engage and to affectively attach towards the hotel brand could be by increasing VC. Marketing actions/ activities can position the brand (hotel) as a salient category in customer's minds, for instance, (i) taking initiatives to develop the hotel brand more appealing to target customers to satisfy their self-verification and/or self-definitional needs and (ii) communicating the hotel brands' values that appeal to and are coherent with customer's values. Moreover, hotel brand mangers require to identifying the importance of $\mathrm{VC}$ because it maintains a long-standing relationship across hotels and their customers. Thus, brand managers have to continuously monitor perceived values of both hotel brand and values of customers to investigate whether an overlap exists between them. The present study also advocates that to increase customer identification and customer engagement, brand managers have to make sure that their brands have strong VC and thereby serve customer's interpersonal goals (Elbedweihy et al., 2016; Islam et al., 2017). This can take place not only because of the promoting of interactions among the brand (hotel) and focal customer through a multitude of approaches, from event marketing to product cocreation, but also because of interactions between customers around a brand, owing to brand communities, both virtual as well as physical (Veloutsou and Guzman, 2017; Stokburger-Sauer et al., 2012; Tuskej and Podnar, 2018).

Customer-brand identification has become one of the key drivers for the strategic development of customer-brand engagement, affective brand commitment and brand loyalty. On the basis of the SEM results, brand identification positively influences customer-brand engagement, confirming that highly identified consumers are more expected to engage with offering/brand. Hospitality companies can build a consistent brand image that matches their customers' identity using advertising and other communication tools. Both actions should increase customer engagement.

The present research suggests that one way of getting customers to engage actively into hotel brand activities can be by strengthening customer-brand identification. Similarly, the relationship between customer-brand identification and affective brand commitment is significant and positive, representing that higher the customer identification towards brand, better is the affective attachments with the brand. Favourable affective commitment is of high relevance in consumer-brand relationship. Customer affective commitment might be revealed owing to product and/or service buying behaviour (Ahearne et al., 2005). In the absence of favourable affective commitment, such a relationship cannot exist (Fatma et al., 2016). In addition, the relationship between customer-brand identification and brand loyalty is also significant and positive, representing that highly identified consumers are most likely to more loyal towards the brand. Today's managers in the service brands face ever increasing challenges in promoting brand loyalty. 
Moreover, measuring the customer-brand engagement effect on loyalty reveals psychological and/or behavioural processes and establishes the connection between consumers and a focal company and/or hotel brand. Such connection steers positive behavioural intentions and persuades re-patronising a hotel brand service. The results imply that customer-brand engagement construct, which is related to customer relationship marketing area, is proven to be an important construct to persuade loyalty within the hospitality brands. In the highly networked era nowadays, a real organisational challenge is the development of loyal customers (Hollebeek et al., 2016a). The current results recommend the espousal of a managerial customer-brand engagement orientation to maintain and build loyalty (Hollebeek et al., 2016a, 2016b; Rather, 2018). Loyalty, thus, contributes to survival and the growth of organisations (Reichheld, 1996). Customer's loyalty effects both long-term as companies gain new consumers, thanks to their consumer's advocacy and favourable comments those consumers make and in the short-term, as loyal customer's likely to purchase more regularly (Reichheld, 1996).

Additionally, hotel brand managers should be aware of the mediation affects while developing their branding and/or marketing practices and strategies. For instance, customer-brand identification mediates the relationship between $\mathrm{VC}$ and customer-brand engagement, VC and affective commitment and VC and brand loyalty. This result underlines the need for hospitality brand management to be aware of the mediation influences while developing their marketing practices to win customer behaviours in the form engagement, affective commitment and brand loyalty.

\section{Limitations and further research}

Even though the present study offers various useful insights, some limitations exist. For example, it has used cross-sectional data; therefore, the future researchers can use a longitudinal study design. Future studies can test the proposed framework by using different methodologies. Researches may replicate the findings of this study under the context of various types of other brands including retail. Finally, the other conceptual frameworks apart from SIT and congruity theory comprising social exchange, social resource and social practice theories can be applied to study the customer-brand identification and customer-brand engagement within the context of hospitality brands. In addition, researchers could broaden their analyses by including additional relational constructs into their model, including co-creation, self-brand connection, brand equity, satisfaction, customer experience or others (Brodie et al., 2013; Hollebeek, 2017; Hollebeek et al., 2016a; Rather and Sharma, 2017b; Rather et al., 2018; Sharma and Rather, 2015).

\section{References}

Ahearne, M., Bhattacharya, C.B. and Gruen, T. (2005), "Antecedents and consequences of customercompany identification: Expanding the role of relationship marketing", Journal of Applied Psychology, Vol. 90 No. 3, pp. 574-585.

Anderson, J.C. and Gerbing, D.W. (1988), "Structural equation modelling in practice: a review and recommended two-step approach", Psychological Bulletin, Vol. 103 No. 3, pp. 411-423.

Bhattacharya, C.B. and Sen, S. (2003), "Consumer company identification: a framework for understanding consumers' relationships with companies”, Journal of Marketing, Vol. 67 No. 2, pp. 76-88.

Brodie, R.J., Hollebeek, L.D., Jurić, B. and Ilić, A. (2011), "Customer Brand engagement: Conceptual domain, fundamental propositions, and implications for research", Journal of Service Research, Vol. 14 No. 3, pp. 252-271. 
Brodie, R.J., Ilic, A., Juric, B. and Hollebeek, L. (2013), "Consumer engagement in a virtual Brand community: An exploratory analysis", Journal of Business Research, Vol. 66 No. 1, pp. 105-114.

Burgess, S.M. and Steenkamp, J.B.E. (2013), "Introduction to the special issue on marketing in emerging markets", International Journal of Research in Marketing, Vol. 30 No. 1, pp. 1-3.

Byrne, D., Griffitt, W. and Stefaniak, D. (1967), "Attraction and similarity of personality characteristics", Journal of Personality and Social Psychology, Vol. 5 No. 1, pp. 82-90.

Dessart, L., Veloutsou, C. and Morgan-Thomas, A. (2015), "Consumer engagement in online Brand communities: a social media perspective", Journal of Product and Brand Management, Vol. 24 No. 1, pp. 28-42.

Dessart, L., Veloutsou, C. and Morgan-Thomas, A. (2016), "Capturing consumer engagement: Duality, dimensionality and measurement”, Journal of Marketing Management, Vol. 32 Nos 5/6, pp. 399-426.

Elbedweihy, A., Jayawardhena, C., Elsharnouby, M.H. and Elsharnouby, T.H. (2016), "Customer relationship building: the role of Brand attractiveness and consumer-Brand identification", Journal of Business Research, Vol. 69 No. 8, pp. 2901-2910.

Erkutlu, H. and Chafra, J. (2016), "Value congruence and commitment to change in healthcare organizations", Journal of Advances in Management Research, Vol. 13 No. 3, pp. 316-333.

Fatma, M., Khan, I. and Rahman, Z. (2016), "How does corporate association influence consumer Brand loyalty? mediating role of Brand identification", Journal of Product and Brand Management, Vol. 25 No. 7, pp. 629-641.

Fornell, C. and Larcker, D.F. (1981), "Evaluating structural equation models with unobservable variables and measurement error", Journal of Marketing Research, Vol. 18 No. 1, pp. 39-50.

Fujita, M., Harrigan, P. and Soutar, G.N. (2018), "Capturing and co-creating student experiences in social media: a social identity theory perspective", Journal of Marketing Theory and Practice, Vol. 26 Nos 1/2, pp. 55-71.

Fullerton, G. (2003), “When does commitment lead to loyalty?”, Journal of Service Research, Vol. 5 No. 4, pp. 333-344.

Hair, J.F., Anderson, R.E., Babin, B.J. and Black, W.C. (2010), “Multivariate Data Analysis: A Global Perspective", Pearson, Upper Saddle River, NJ, Vol. 7.

Hapsari, R., Clemes, M.D. and Dean, D. (2017), "The impact of service quality, customer engagement and selected marketing constructs on airline passenger loyalty", International Journal of Quality and Service Sciences, Vol. 9 No. 1, pp. 21-40.

Harrigan, P., Evers, U., Miles, M.P. and Daly, T. (2017), "Customer Brand engagement and the relationship between involvement, engagement, self-Brand connection and Brand usage intent", Journal of Business Research, Vol. 88, pp. 388-396.

He, H., Li, Y. and Harris, L. (2012), "Social identity perspective on Brand loyalty", Journal of Business Research, Vol. 65 No. 5, pp. 648-657.

Hollebeek, L. (2011b), "Exploring customer Brand engagement: definition and themes", Journal of Strategic Marketing, Vol. 19 No. 7, pp. 555-573.

Hollebeek, L.D. (2011a), "Demystifying customer Brand engagement: Exploring the loyalty nexus", Journal of Marketing Management, Vol. 27 Nos 7/8, pp. 785-807.

Hollebeek, L.D. (2017), "Individual-level cultural consumer engagement styles: Conceptualization, propositions, and implications", International Marketing Review, Vol. 35 No. 1, pp. $42-71$.

Hollebeek, L.D. (2018), "Individual-level cultural consumer engagement styles: conceptualization, propositions, and implications”, International Marketing Review, (In press).

Hollebeek, L.D. and Chen, T. (2014), "Exploring positively-versus negatively-valenced Brand engagement: a conceptual model", Journal of Product and Brand Management, Vol. 23 No. 1, pp. 62-74.

Hollebeek, L.D., Conduit, J. and Brodie, R.J. (2016a), "Strategic drivers, anticipated and unanticipated outcomes of customer Brand engagement", Joumal of Marketing Management, Vol. 32 Nos 5/6, pp. 393-398. 
Hollebeek, L.D., Glynn, M.S. and Brodie, R.J. (2014), "Consumer Brand engagement in social media: Conceptualization, scale development and validation", Journal of Interactive Marketing, Vol. 28 No. 2, pp. 149-165.

Hollebeek, L.D., Srivastava, R.K. and Chen, T. (2016b), "SD logic-informed customer Brand engagement: integrative framework, revised fundamental propositions, and application to CRM", Journal of the Academy of Marketing Science, (In press).

Islam, J.U. and Rahman, Z. (2016), "The transpiring journey of customer Brand engagement research in marketing: a systematic review of the past decade", Management Decision, Vol. 54 No. 8,

Customer brand engagement and brand loyalty pp. 2008-2034.

Islam, J.U., Rahman, Z. and Hollebeek, L.D. (2017), "Consumer engagement in online Brand communities: a solicitation of congruity theory", Internet Research, Vol. 28 No. 1, pp. 23-45.

Johar, J.S. and Sirgy, M.J. (1991), "Value-expressive versus utilitarian advertising appeals: When and why to use which appeal", Journal of Advertising, Vol. 20 No. 3, pp. 23-33.

Kuenzel, S. and Halliday, S.V. (2008), "Investigating antecedents and consequences of Brand identification", Journal of Product and Brand Management, Vol. 17 No. 5, pp. 293-304.

Kumar, V. and Pansari, A. (2016), "Competitive advantage through engagement”, Journal of Marketing Research, Vol. 53 No. 4, pp. 497-514.

Lam, S.K., Ahearne, M., Mullins, R., Hayati, B. and Schillewaert, N. (2013), "Exploring the dynamics of antecedents to consumer-Brand identification with a new Brand", Journal of the Academy of Marketing Science, Vol. 41 No. 2, pp. 234-252.

Lam, S.K., Ahearne, M. and Schillewaert, N. (2012), "A multinational examination of the symbolicinstrumental framework of consumer-Brand identification", Journal of International Business Studies, Vol. 43 No. 3, pp. 306-331.

Lee, S.A. and Jeong, M. (2014), "Enhancing online Brand experiences: An application of congruity theory", International Journal of Hospitality Management, Vol. 40, pp. 49-58.

Liu, F., Li, J., Mizerski, D. and Soh, H. (2012), "Self-congruity, Brand attitude, and Brand loyalty: a study on luxury brands", European Journal of Marketing, Vol. 46 Nos 7/8, pp. 922-937.

Marketing Science Institute (2016), "Research Priorities 2016-2018", Marketing Science Institute, Boston, MA.

Martinez, P. and Rodriguez Del Bosque Rodriguez, I. (2013), "CSR and customer loyalty: the roles of trust, customer identification with the company and satisfaction", International Journal of Hospitality Management, Vol. 35, pp. 89-99.

Odoom, R., Boateng, H. and Asante, B.O. (2017), "An empirical investigation of perceived relational benefits and Brand engagement in restaurant services", International Journal of Contemporary Hospitality Management, Vol. 29 No. 11, pp. 2767-2784.

Pansari, A. and Kumar, V. (2017), "Customer engagement: the construct, antecedents, and consequences", Journal of the Academy of Marketing Science, Vol. 45 No. 3, pp. 294-311.

Parrey, S.H., Hakim, I.A. and Rather, R.A. (2018), "Mediating role of government initiatives and media influence between perceived risks and destination image: a study of conflict zone", International Journal of Tourism Cities, (In press).

Rather, R.A. (2017), "Investigating the impact of customer Brand identification on hospitality Brand loyalty: a social identity perspective", Journal of Hospitality Marketing and Management, Vol. 27 No. 5, pp. 487-513.

Rather, R.A. (2018), "Consequences of consumer engagement in service marketing: An empirical exploration", Journal of Global Marketing, (In press).

Rather, R.A. and Shakir, P.H. (2018), "Customer engagement in increasing affective commitment within hospitality sector", Journal of Hospitality Application and Research, Vol. 13 No. 1, pp. 72-91. 
SJME

22,3

Rather, R.A. and Sharma, J. (2017b), "The effects of customer satisfaction and commitment on customer loyalty: Evidence from the hotel industry", Journal of Hospitality Application and Research, Vol. 12 No. 2, pp. 41-60.

Rather, R.A., Sharma, J. and Itoo, M.H. (2018), "Exploring relationships among customer Brand engagement, Brand equity and Brand loyalty towards hospitality brands", Abhigyan, (In press).

Rather, R.A. and Sharma, J. (2017a), "Customer Brand engagement for evaluating customer relationships in hotel industry", European Journal of Tourism, Hospitality and Recreation, Vol. 8 No. 1, pp. 1-13.

Reichheld, F.F. (1996), "The Loyalty Effect: The Hidden Force behind Growth, Profits, and Lasting Value, Bosto", Harvard Business School Press, MA.

Romero, J. (2017), "Customer Brand engagement behaviors in hospitality: Customer-based antecedents", Journal of Hospitality Marketing and Management, Vol. 26 No. 6, pp. 565-584.

Ruyter, K.D., Moorman, L. and Lemmink, J. (2001), "Antecedents of commitment and trust in customer supplier relationships in high technology markets", Industrial Marketing Management, Vol. 30 No. 3, pp. 271-286.

Sharma, J. and Rather, R.A. (2015), "Understanding the customer experience: An exploratory study of “A”, Category Hotels", International Journal on Customer Relations, Vol. 3 No. 2, pp. 21-31.

Sharma, J. and Rather, R.A. (2016), "The role of customer Brand engagement in ensuring sustainable development in hospitality sector", International Journal of Hospitality and Tourism Systems, Vol. 9 No. 1, pp. 33-43.

Sheth, J.N. (2011), "Impact of emerging markets on marketing: Rethinking existing perspectives and practices", Journal of Marketing, Vol. 75 No. 4, pp. 166-182.

So, K.K.F., King, C., Hudson, S. and Meng, F. (2017), "The missing link in building customer Brand identification: the role of Brand attractiveness", Tourism Management, Vol. 59, pp. 640-651.

So, K.K.F., King, C., Sparks, B. and Wang, Y. (2013), "The influence of customer Brand identification on hotel Brand evaluation and loyalty development", International Journal of Hospitality Management, Vol. 34, pp. 31-41.

So, K.K.F., King, C., Sparks, B.A. and Wang, Y. (2014), "The role of customer Brand engagement in building consumer loyalty to tourism brands", Journal of Travel Research, Vol. 55 No. 1, pp. 64-78.

Stokburger-Sauer, N., Ratneshwar, S. and Sen, S. (2012), "Drivers of consumer Brand identification", International Journal of Research in Marketing, Vol. 29 No. 4, pp. 406-418.

Su, L., Swanson, S.R., Chinchanachokchai, S., Hsu, M.K. and Chen, X. (2016), "Reputation and intentions: the role of satisfaction, identification, and commitment", Journal of Business Research, Vol. 69 No. 9, pp. 3261-3269.

Tajfel, H. and Turner, J.C. (1979), "An integrative theory of intergroup conflict", in Austin, W.G. and Worchel, S. (Eds), The Social Psychology of Intergroup Relations, Monterey, CA: Brooks-Cole, pp. 33-47.

Tuskej, U., Golob, U. and Podnar, K. (2013), "The role of consumer-Brand identification in building Brand relationships”, Journal of Business Research, Vol. 66 No. 1, pp. 53-59.

Tuskej, U. and Podnar, K. (2018), “Consumers' identification with corporate brands: Brand prestige, anthropomorphism and engagement in social media", Journal of Product and Brand Management, Vol. 27 No. 1, pp. 3-17.

Van Doorn, J., Lemon, K.N., Mittal, V., Nass, S., Pick, D., Pirner, P. and Verhoef, P.C. (2010), “Customer Brand engagement behavior: Theoretical foundations and research directions", Journal of Service Research, Vol. 13 No. 3, pp. 253-266.

Vargo, S.L. and Lusch, R. (2017), "S-D logic 2025", International Journal of Research in Marketing, Vol. 34 No. 1, pp. 46-67. 
Veloutsou, C. and Guzman, F. (2017), "The evolution of Brand management thinking over the last 25 years as recorded in the journal of product and Brand management", Journal of Product and Brand Management, Vol. 26 No. 1, pp. 2-12.

Vivek, S.D., Beatty, S.E. and Morgan, R.M. (2012), "Customer engagement: exploring customer relationships beyond purchase", Journal of Marketing Theory and Practice, Vol. 20 No. 2, pp. 122-146.

Customer brand engagement and brand loyalty

Vivek, S.D., Beatty, S.E., Dalela, V. and Morgan, R.M. (2014), “A generalized multidimensional scale for measuring customer Brand engagement", Journal of Marketing Theory and Practice, Vol. 22 No. 4, pp. 401-420.

Wu, X., Zhou, H. and Wu, D. (2011), "Commitment, satisfaction, and customer loyalty: a theoretical explanation of the 'satisfaction trap", The Service Industries Journal, Vol. 32 No. 11, pp. 1759-1774.

Zhang, J. and Bloemer, J. (2011), "Impact of value congruence on affective commitment: examining the moderating effects", Journal of Service Management, Vol. 22 No. 2, pp. 160-182.

Zhao, X., Lynch, J.G. and Chen, Q. (2010), "Reconsidering baron and kenny: myths and truths about mediation analysis", Journal of Consumer Research, Vol. 37 No. 2, pp. 197-206.

\section{Further reading}

Escalas, J.E. and Bettman, J.R. (2003), "You are what they eat: the influence of reference groups on consumers connections to brands", Journal of Consumer Psychology, Vol. 13 No. 3, pp. 339-348.

Rather, R.A. and Sharma, J. (2016), "Customer Brand engagement in strengthening customer loyalty in hospitality sector", South Asian Journal of Tourism and Heritage, Vol. 9 No. 2, pp. 62-81.

\section{About the authors}

Raouf Ahmad Rather, MBA (Marketing), is a full-time Sponsored Research Scholar, working on research in the area of customer engagement, co-creation, service innovation, brand identification and loyalty, while pursuing his $\mathrm{PhD}$ in marketing management at the Business School, University of Jammu, Jammu and Kashmir, India. His work thus far has been published in journals, including the Journal of Hospitality Marketing and Management; Journal of Global Marketing; International Journal of Tourism Cities: European Journal of Tourism, Hospitality and Recreation; International Journal of Hospitality and Tourism Systems; and South Asian Journal of Tourism and Heritage. Raouf Ahmad Rather is the corresponding author and can be contacted at: r.raouf18@gmail.com

Dr Shehnaz Tehseen, PhD in management, works as a full-time Lecturer in the Department of Management, Sunway University Business School, Sunway University, Malaysia. Her research interests lie in the areas of entrepreneurship, ethnic entrepreneurship, SMEs, cultural orientations, innovation, entrepreneurial competencies, retail sector, human resource management, strategic management, knowledge management, marketing, consumer behaviour, hospitality, tourism and organisational behaviour. Her work has appeared in journals such as the International Journal of Trade and Global Markets, Mediterranean Journal of Social Sciences, International Journal of Entrepreneurship and Journal of Management Sciences as well as in many non-referred journals.

Dr Shakir Hussain Parrey, PhD in management, works as a Lecturer in the University of Kashmir and Research Associate, Department of Management Studies, University of Kashmir, Jammu and Kashmir, India. His research interests lie in the areas of agri-allied entrepreneurship, risk analysis, behavioural evaluation, consumer behaviour and organisational behaviour. His work has been published in journals including the International Journal of Tourism Cities; Vikalpa: The Journal for Decision Makers; Journal of Entrepreneurship and Management; and Journal of Hospitality Application and Research.

For instructions on how to order reprints of this article, please visit our website:

www.emeraldgrouppublishing.com/licensing/reprints.htm

Or contact us for further details: permissions@emeraldinsight.com 
